\title{
Un nuevo cuaderno
}

Por Leydi De Ávila William Hurtado ${ }^{1}$

Universidad de Cartagena

\author{
Cuaderno. Revista del Taller de \\ Escritura Creativa "Coloquio", \\ $n^{\circ}$ 2-3 (Junio), Cartagena, Edi- \\ torial Universitaria-Universi- \\ dad de Cartagena, 2012, 124p.
}

La revista Cuaderno es el resultado de un largo camino: individual primero, colectivo después.Todo comienza con las ganas o la necesidad de escribir, de contar una historia, de expresar un modo de sentir, o pensar. Esa urgencia no es nueva ni esnob, sino genuina en cada uno de los participantes que la realizan; es un impulso que

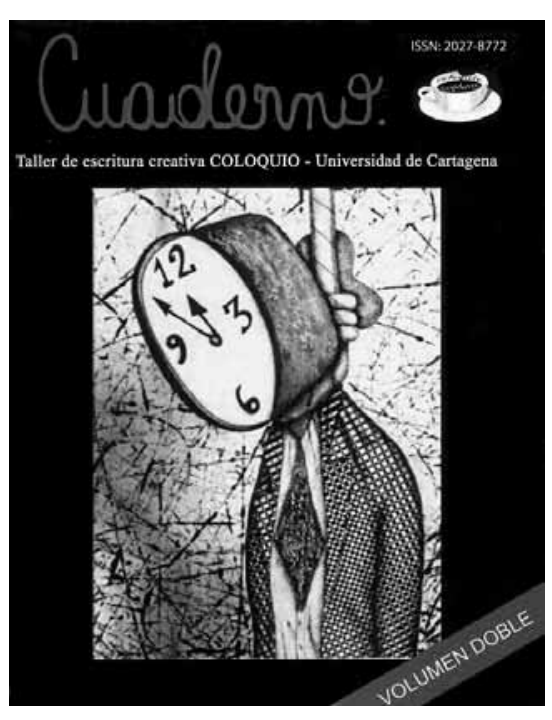
se halla encadenado a otras exigencias reales y actuantes antes de formar parte de "Coloquio", el Taller de Escritura Creativa de la Universidad de Cartagena. Por eso se ha vuelto sentencia eso de que aquí no venimos a aprender a escribir; estamos aquí porque ya escribimos.

El "tallereo" de cada texto es un paso que hace que este proceso sea de todos los que conforman el grupo. Es el momento en que nos hacemos unidad, a pesar de las diferentes voces, porque el tejido de voluntades nos permite tamizar y llegar, ahora sí, a acuerdos, a eso que parece moverse solo y es la materia prima que conforma el Cuaderno: escritura en la que se configuran formas y sentidos. A partir de ella todas esas voces llegan a una misma pista de aterrizaje, encontrando ahí una continua supervivencia, a pesar de las distintas realidades que expresan. Detrás de cada texto palpita el arduo trabajo de una huida lenta y gradual del propio ser, pero también la presencia de los demonios que circundan a todos y a cada uno de los talleristas.

Este Cuaderno es la evidencia de la pérdida de cualquier cautela exigida por la vida para andar sobre ella; es la manera más concreta y atrevida de suspenderse en un vacío sin fondo ni orillas, saboreando

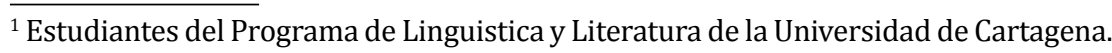
Miembros del Taller de Escritura Creativa “Coloquio" de la misma universidad. 
cada palabra que acude al auxilio. Muestra la forma que le ha dado a su inconformidad cada miembro del taller, en el proceso de constituirse.

Cuaderno es también la meta provisional, permanentemente renovada, del propósito de adquirir un compromiso con la escritura, asumido seriamente. Articula una compleja visión de mundo que multiplica la mirada de cada uno de sus integrantes después de recorrer el adentro de su propio ser, de sus sensaciones, de sus experiencias. Es el acto de escarbar la tierra que recubre los pensamientos, para recuperar los atavismos de una generación que se niega a estancarse, aun cuando ofrezca su carne a la mordedura de la muerte. Es el resumen de uno de los tantos modos de domarse a sí mismo y a las tempestades aterradoras e inimaginables que caracterizan al hombre luego de abrazar el mundo en su horrorosa contradicción. En Cuaderno las maneras de mostrar la vida tienen que ver con la búsqueda de la perfección a través de la palabra, pero también con el reconocimiento de su capacidad para identificar lo imperfecto, logrando hacer de la realidad un camino que se bifurca en rutas que reclaman alternativas para escoger y perderse en cualquiera de ellas.

Después de todo esto, tres pasos finales ponen en manos delos lectores la nueva edición de Cuaderno. El primero: el empeño de nuestra editora Márgareth Ríos Hernández gracias al cual este volumen es una realidad; segundo: la gestión oportuna para lograr el apoyo de las directivas de la Universidad de Cartagena, que correspondieron a los esfuerzos de "Coloquio"; y tercero, el encuentro con los lectores, de quienes esperamos su valoración a través del blog. http://coloquioudec.blogspot.com/

Este volumen doble trae por primera vez una sección que será permanente: Escritor invitado, dedicada, como un afectuoso homenaje, al maestro y amigo Rómulo Bustos Aguirre. En este volumen se destaca a Marleys Meléndez Moré, por los logros alcanzados con humildad y persistencia. Reconoce los aciertos de Márgareth Ríos y Juan Manuel González Sequeda, finalistas en importantes concursos literarios, y se enorgullece de contar con la presencia de Jair Buelvas Caro, Astrid Rosandy Cárdenas, Javier Córdoba Cuevas, Leydi De Ávila, Fabio Gallo, Hernán Grey Zapateiro, William Hurtado Gómez, Juan David Mogollón, María Angélica Montes, Hailher Salcedo y María Alejandra Zambrano.

Por lo demás, gracias a Ernesto Fidel Quetzalcoatl y a Barzal por autorizar el uso de las imágenes de su autoría que ilustran el volumen. Se incluye también el ensayo "Una poética de lo inefable", de nuestro animador Raymundo Gomezcásseres, dedicado a comentar la antología personal de Rómulo Bustos Aguirre. 